\title{
Profil Pemecahan Masalah Nilai Ekstrim Ditinjau dari Perbedaan Gender
}

\author{
Sefni Oemolos ${ }^{1}$, Helti Lygia Mampouw ${ }^{2}$ \\ 1, 2Program Studi Pendidikan Matematika, Universitas Kristen Satya Wacana \\ Jl. Diponegogo No. 52 - 60, Salatiga, Jawa Tengah 50711, Indonesia \\ 202017037@student.uksw.edu
}

\begin{abstract}
This study aims to describe the profile of problems related to extreme scores in terms of gender differences in class XII MIPA 2 students of Satya Wacana Christian High School, Salatiga. Profiles of problem problems which are in the Polya stage. This type of research is a qualitative descriptive study. The technique of taking the subject using purposive sampling obtained 6 subjects with a category of mathematical ability in terms of gender differences, so students with a high mathematical ability category in male gender who passed the Polya stage appropriately, be it the stage of understanding the problem, compiling a problem plan, implementing plans to monitor the problem. and check back. Whereas students in gender experience errors at the stage of compiling this problem plan, working on problems and checking again. Students with moderate and low math abilities, both male and female, still experience errors at the stage of preparing problem plans, implementing problem plans and checking again.
\end{abstract}

Keywords: Problem Solving, Extreme Value, Gender Differences, Polya Stages

\section{Abstrak}

Penelitian ini bertujuan untuk mendeskripsikan profil pemecahan masalah yang berkaitan dengan nilai ektrim ditinjau dari perbedaan gender pada siswa kelas XII MIPA 2 SMA Kristen Satya Wacana Salatiga. Profil pemecahan masalah yang dianalisis berdasarkan tahapan Polya. Jenis Penelitian ini adalah penelitian deskriptif kualitatif. Teknik pengambilan subjek menggunakan purposive sampling diperoleh 6 subjek dengan kategori berkemampuan matematika ditinjau dari perbedaan gender maka siswa dengan kategori kemampuan matematika tinggi pada gender laki-laki yang melewati semua tahapan Polya dengan tepat, baik itu tahap memahami masalah, menyusun rencana pemecahan masalah, melaksanakan rencana pemecahan masalah dan memeriksa kembali. Sedangkan siswa pada gender perempuan mengalami kesalahan pada tahap menyusun rencana pemecahan masalah, melaksanakan rencana pemecahan masalah dan memeriksa kembali. Siswa dengan kemampuan matematika sedang dan rendah baik dari gender laki-laki dan perempuan masih mengalami kesalahan pada tahap menyusun rencana pemecahan masalah, melaksanakan rencana pemecahan masalah dan memeriksa kembali.

Kata kunci: Pemecahan Masalah, Nilai Ekstrim, Perbedaan Gender, Tahapan Polya

Copyright (c) 2021 Sefni Oemolos, Helti Lygia Mampouw

Corresponding author: Sefni Oemolos

Email Address: 202017037@student.uksw.edu (Jl. Diponegogo No. 52 - 60, Salatiga, Jawa Tengah 50711)

Received 27 April 2021, Accepted 05 May 2021, Published 06 May 2021

\section{PENDAHULUAN}

Matematika merupakan salah satu mata pelajaran yang sangat penting dalam kehidupan seharihari. Matematika mempunyai peranan yang cukup penting dalam kehidupan karena banyak hal yang harus diselesaikan dengan masalah hitungan sehingga terus dipelajari dari tingkat sekolah dasar hingga ke tingkat perguruan tinggi. Matematika sangat dibutuhkan untuk memudahkan pemecahan masalah dalam kehidupan sehari-hari. Contohnya dalam bidang matematika ketika mau membuat kolam ikan, menanam tanaman di kebun, dan membuat kandang ayam. Dalam bidang fisika dibahas mengenai laju perubahan suatu benda, misalnya jarum penunjuk speedometer motor/mobil ketika bergerak. Matematia membentuk pola pikir secara logis dengan harapan siswa dapat mengaplikasikan materi tersebut dalam kehidupan sehari-hari. Dalam Pujiadi (2016) mengenai kurikulum matematika dan pemanfaatan media 
pembelajaran bahwa mata pelajaran matematika bertujuan agar siswa dapat menerapkan konsep secara logis. Agar siswa atau anak dapat menyelesaikan pemecahan masalah yang dilakukan dalam kehidupan sehari-hari maka di sekolah ada mata pelajaran matematika. Mata pelajaran matematika materimaterinya disesuaikan dengan tahap perkembangan kognitif siswa menurut Piaget.

Materi di sekolah disesuaikan dengan tahap kognitif siswa menurut Piaget. (Mu'min, 2013) Piaget meyakini bahwa perkembangan kognitif terbagi dalam empat bagian, masing-masing bagian berhubungan dengan jalan pikiran dan tersusunnya usia yang berbeda. Menurut Piaget, kualitas kemajuannya berbeda-beda semakin banyak informasi tidak membuat pikiran anak lebih maju. Bagianbagian perkembangan kognitif adalah bagian sensorik motorik ( $0-2$ tahun), bagian pra-operasional (usia 2-7 tahun), bagian operasional konkret (usia 7-11 tahun), dan bagian operasional formal (usia 11-15 tahun). Usia sebelas sampai lima tahun individu sudah mulai memikirkan secara lebih abstrak, pengalaman konkret, idealis dan logis. Kualitas abstrak dari pemikiran operasional formal tampak jelas dalam pemecahan masalah. Oleh karena itu siswa seharusnya sudah berhasil menguasai materi dengan tingkat satuannya karena sudah diatur dalam Permendikbud.

Permendikbud No. 37 Tahun 2018 tentang kompetensi inti dan kompetensi dasar memuat kompetensi yang harus dimiliki oleh siswa SD sampai SMA pada kurikulum 2013. Terdapat 4 kompetensi yang dimiliki siswa, yaitu sikap spiritual, sikap sosial, pengetahuan, dan keterampilan. Kompetensi pengetahuan dan keterampilan tentang nilai maksimum dan nilai minimum dirumuskan dalam kompetensi dasar tingkat SMA, kenyataannya siswa SMA banyak yang terkendala dalam belajar tentang nilai esktrim, hasil-hasil belajar matematika di Indonesia belum memuaskan. (Kristianingsih, 2019), menuliskan hasil penelitian Trends in Mathematics and Science Study (TIMSS) menyatakan hasilhasil belajar siswa di Indonesia dalam menyelesaikan soal-soal belum memuaskan. Keterlibatan Indonesia dalam TIMSS sejak tahun 1999 hingga 2015, dalam bidang matematika Indonesia berada pada bagian bawah yaitu rangking 45 dari 50 negara dengan skor 397. Hasil survey Programme for International Student Assesment (PISA) siswa di Indonesia masih mengalami kesulitan dalam menyelesaikan soal-soal. PISSA berpusat dibawah lindungan Organisasi Kerja Sama Ekonomi dan Pembangunan (OECD) yang bertujuan untuk mengukur tingkat kemampuan siswa berusia 15 tahun disuatu negara dalam bentuk literasi membaca, matematika dan sains. Indonesia menempati peringkat ke-63 dari 70 negara pada tahun 2015. Negara yang berada dikawasan Asia Tenggara, di mana Indonesia kalah jauh dari Vietnam yang menempati peringkat ke-12, bahkan Singapura berada pada peringkat pertama. Menganalisa, memahami dan mengaplikasikan ilmu-ilmu dasar adalah aspek yang diukur dalam matematika yang digunakan dalam kehidupan sehari-hari. Penguasaan matematika yang kuat akan memberikan peluang yang besar memudahkan dalam memahami masalah-masalah matematika dalam kehidupan sehari-hari. Berikut ini adalah daya serap nilai ekstrim hasil pamer Ujian Nasional 3 tahun terakhir untuk jurusan IPA. 
Tabel 1. Daya serap Nilai Ekstrim hasil pamer Ujian Nasional 3 tahun terakhir untuk jurusan IPA

\begin{tabular}{|c|c|c|c|c|c|c|}
\hline \multirow{2}{*}{$\begin{array}{l}\text { Tahun } \\
\text { Pelajaran }\end{array}$} & \multirow{2}{*}{$\begin{array}{l}\text { No } \\
\text { Urut }\end{array}$} & \multirow[b]{2}{*}{ Indikator } & \multicolumn{4}{|c|}{ Presentase Daya Serap Siswa (\%) } \\
\hline & & & Nasional & $\begin{array}{c}\text { Jawa } \\
\text { Tengah }\end{array}$ & $\begin{array}{c}\text { Kota } \\
\text { Semarang }\end{array}$ & $\begin{array}{c}\text { Kota } \\
\text { Salatiga }\end{array}$ \\
\hline $2016 / 2017$ & 24 & $\begin{array}{l}\text { Peserta didik dapat } \\
\text { menyelesaikan permasalahan } \\
\text { yang berkaitan dengan aplikasi } \\
\text { turunan }\end{array}$ & $37,52 \%$ & $40,01 \%$ & $41,61 \%$ & $45,29 \%$ \\
\hline $2017 / 2018$ & 19 & $\begin{array}{l}\text { Menentukan nilai } \\
\text { maksimum/minimum dari } \\
\text { masalah tersebut dengan konsep } \\
\text { turunan pada permasalahan nilai } \\
\text { ekstrim }\end{array}$ & $32,46 \%$ & $35,54 \%$ & $36,98 \%$ & $45,69 \%$ \\
\hline $2018 / 2019$ & 19 & $\begin{array}{l}\text { Menyelesaikan masalah } \\
\text { konstektual yang berkaitan } \\
\text { dengan ekstrim fungsi }\end{array}$ & $31,94 \%$ & $38,92 \%$ & $42,17 \%$ & $49,05 \%$ \\
\hline
\end{tabular}

Sumber:https://hasilun.puspendik.kemdikbud.go.id/\#2019!sma!daya serap!03\&05\&999!a\&03\&T\&T $\& 1 \& ! 3 ! \&$

Hasil belajar peserta didik yang tidak sesuai dengan kompetensi pada kurikulum, peneliti menggunakan proses pemecahan masalah oleh siswa menggunakan tahapan Polya. Polya (Nur dan Rahman, 2013) memperkenalkan model, prosedur atau langkah-langkah pemecahan masalah matematika yang terdiri atas tahapan-tahapan pemecahan masalah, yaitu (1) memahami masalah; (2) membuat rencana; (3) melaksanakan rencana pemecahan; dan (4) menelaah kembali. Tahapan pemecahan masalah Polya tersebut merupakan aspek-aspek yang banyak digunakan untuk mengukur kemampuan pemecahan masalah matematika siswa. Bukti-bukti penelitian terdahulu berdasarkan tahapan Polya yaitu, tahapan pemecahan masalah Polya tersebut merupakan aspek-aspek yang banyak digunakan untuk mengukur kemampuan pemecahan masalah matematika siswa. Bukti-bukti penelitian terdahulu berdasarkan langkah Polya yaitu (a) (Sam \& Qohar, 2016), (b) (Netriwati, 2016), (c) (Yarmayani, 2016), (d) (Irianti et al., 2016), (e) (Susilowati, AsihPutri, 2016), (f) (Kristofora \& Sujadi, 2017), (g) (Nur \& Palobo, 2018), (h) (Vilianti et al., 2018), (i) (Yuwono et al., 2018), j) (Abdiyani et al., 2019), (k ) (Zakiah et al., 2019), (l) (Maulyda et al., 2019), (m) (Yulianto et al., 2019) dan yang meneliti materi integral yaitu (Christinove \& Mampouw, 2019), hasil penelitian ini dapat menjadi acuan untuk mengantisipasi dan mengurangi kesalahan siswa dalam menghitung integral pasti serta yang meneliti tentang kesulitan siswa dalam menyelesaikan soal cerita matematika topik pecahan ditinjau dari perbedaan gender yaitu (Aminah \& Ayu Kurniawati, 2018). Berdasarkan hasil penelitian oleh peneliti terlebih dahulu bahwa tahapan Polya dapat meningkatkan hasil pembelajaran siswa.

Nilai ekstrim merupakan salah satu materi yang diajarkan ditingkat Sekolah Menengah Atas pada siswa kelas XI. Untuk memiliki pemahaman yang jelas tentang konsep turunan, materi fungsi secara umum sangat penting untuk mempelajari konsep turunan. Salah satu penyebab kegagalan siswa dalam mempelajari nilai ekstrim dikarenakan siswa memiliki skema yang lemah terhadap turunan sehingga siswa tidak dapat menghubungkan konsep yang terkait dalam menemukan penyelesaian permasalahan 
berkaitan dengan nilai maksimum dan minimum (Burns, 2014). Siswa dalam memecahkan masalah matematika materi nilai ekstrim memiliki kemampuan yang beragam berdasarkan tingkat pemahaman siswa terhadap suatu masalah yang dikaitkan dengan konsep yang dimiliki siswa sebelumnya termasuk kemampuan matematika antara anak laki-laki dan perempuan atau perbedaan gender di sekolah.

Gender merupakan karakteristik yang membedakan siswa dalam belajar dan mengolah informasi. Laporan NAPLAN (National Assessment Program-Literacy and Numeracy) mengatakan bahwa anak laki-laki secara teratur mengalahkan anak perempuan di berhitung, dan anak perempuan secara konsisten mengalahkan anak laki-laki dalam membaca, menulis, mengeja, dan tata bahasa (Leder, Forgasz, \& Jackson, 2014). Zhu (2007) mendapati adanya perbedaan pemecahan matematika dipengaruhi perbedaan gender, perbedaan pengalaman dan perbedaan pendidikan.

Pemecahan masalah merupakan suatu upaya yang dilakukan untuk menyelesaikan permasalahan yang ditemukan. Pemecahan masalah dalam metematika sendiri merupakan suatu usaha yang dimiliki siswa dalam menyelesaikan soal matematika dengan melibatkan semua bekal pengetahuan dan pengalaman yang dimilikinya. Pentingnya pemecahan masalah dalam kehidupan sehari-hari yang terkait dengan nilai ekstrim di mana hasil data-data menunjukan bahwa di Indonesia masih lemah maka dibuatlah penelitian ini yang bertujuan untuk mengetahui dan mendeskripsikan profil pemecahan masalah nilai ekstrim ditinjau dari perbedaan gender pada siswa kelas XII MIPA 2 SMA Kristen Satya Wacana Salatiga yang dianalisis berdasarkan tahapan Polya.

\section{METODE}

Metode penelitian yang dipakai dalam penelitian ini adalah metode deskriptif kualitatif. Dalam (Yarmayani, 2016) Penelitian kualitatif merupakan metode penelitian yang digunakan untuk meneliti pada kondisi objek yang alami. Adapun pendekatan dalam penelitian ini adalah pendekatan deskriptif yang bertujuan untuk mendeskripsikan apa yang saat ini berlaku. Menurut Bogdan dan Taylor (Rofiqoh, 2015:44) pendekatan kualitatif adalah suatu prosedur penelitian yang menghasilkan data berupa katakata tertulis atau lisan dari orang-orang dan perilaku yang dapat diamati.

Subjek penelitian ini adalah 6 siswa kelas XII MIPA 2 dengan syarat yang sudah mempelajari materi turunan fungsi, dan subjek dibedakan dari perbedaan gender dan kemampuan matematika. Cara memilih subjeknya dengan teknik purposive sampling. Menurut Sugiono (2008) purposive adalah teknik pengambilan sampel dengan menentukan kriteria-kriteria tertentu. Selain itu peneliti memberikan soal tes kepada seluruh siswa kelas XII MIPA 2 SMA Kristen Satya Wacana Salatiga sebanyak 27 siswa, dalam bentuk online dan yang menjawab hanya 13 siswa, diarahkan melalui google meet instrumen tes diunggah lewat google classroom kemudian jawabannya dikirim melalui whatsApp peneliti supaya mudah mendapatkan kontak fokus subjek yang mau diteliti yaitu 6 siswa untuk diwawancarai dilihat dari tingkat kemampuan matematika dan perbedaan gender, yaitu siswa berkemampuan matematika tingkat tinggi 2 siswa, sedang 2 siswa dan rendah 2 siswa. Tempatnya di SMA Kristen Satya Wacana Salatiga. 
Tabel 2. subjek penelitian berdasarkan kategori dan perbedaan gender

\begin{tabular}{|c|c|c|c|c|}
\hline $\begin{array}{c}\text { Nama (Inisial) } \\
\text { Laki-laki }\end{array}$ & $\begin{array}{c}\text { Rata-rata } \\
\text { Nilai }\end{array}$ & $\begin{array}{c}\text { Nama (Inisial) } \\
\text { Perempuan }\end{array}$ & $\begin{array}{c}\text { Rata-rata } \\
\text { Nilai }\end{array}$ & Kategori \\
\hline VPUR & 96,9 & GHD & 90 & Tinggi \\
\hline EA & 84,75 & LS & 83,12 & Sedang \\
\hline JRA & 72,12 & VS & 61,9 & Rendah \\
\hline
\end{tabular}

Peneliti merupakan instrumen utama dalam pengumpulan data dan menginterpretasi data dengan lembar pemetaan kemampuan siswa dan pedoman wawancara. Lembar pemetaan kemampuan siswa memuat soal tentang nilai maksimum dan minimum fungsi serta pedoman wawancara digunakan untuk mengambil data tentang pemecahan masalah siswa dengan tahapan Polya. Pendekatan penelitian peneliti merupakan instrumen utama dalam mengumpulkan data dan juga melakukan survey pada google classroom guru mata pelajaran matematika kelas XII MIPA. Setelah itu menggunakan data yang diperoleh dari rata-rata nilai tugas limit fungsi dan turunan fungsi trigonometri semester gasal tahun ajaran 2020/2021. Kemudian dari hasil nilai tersebut siswa dikelompokan kedalam tiga kategori nilai matematika, yaitu siswa kategori tinggi, sedang dan rendah ditinjau dari perbedaan gender berdasarkan tahapan Polya.

Analisis data dalam penelitian ini dilakukan melalui tiga kegiatan yang terjadi secara bersamaan yaitu reduksi data, penyajian data, dan penarikan kesimpulan atau verifikasi, Miles dan Huberman (Sugiyono, 2015). Analisis data kualitatif merupakan upaya yang berlanjut, berulang dan menerus. Masalah reduksi data, penyajian data, dan penarikan kesimpulan merupakan rangkaian kegiatan analisis yang saling susul menyusul. Kegiatan analisis data penelitian terdiri dari 3 langkah, yaitu reduksi data, display data, dan kesimpulan atau verifikasi.

\section{HASIL DAN DISKUSI}

\section{Tahap Memahami Masalah}

Untuk tahap memahami masalah keenam subjek ini sudah melewati tahap ini berdasarkan hasil tes dan wawancara. Hasil yang diperoleh dari penelitian yang telah dilakukan terhadap subjek melalui tahap memahami masalah dilakukan dengan lancar dan benar. Namun beberapa subjek masih melakukan kesalahan pada tahap ini yaitu subjek VS sudah menuliskan apa yang diketahui tetapi masih mengalami kesalahan, apa yang dituliskan belum sesuai dengan informasi dalam soal yaitu kurang menuliskan satuannya sehingga menyebabkan hasilnya kurang tepat.

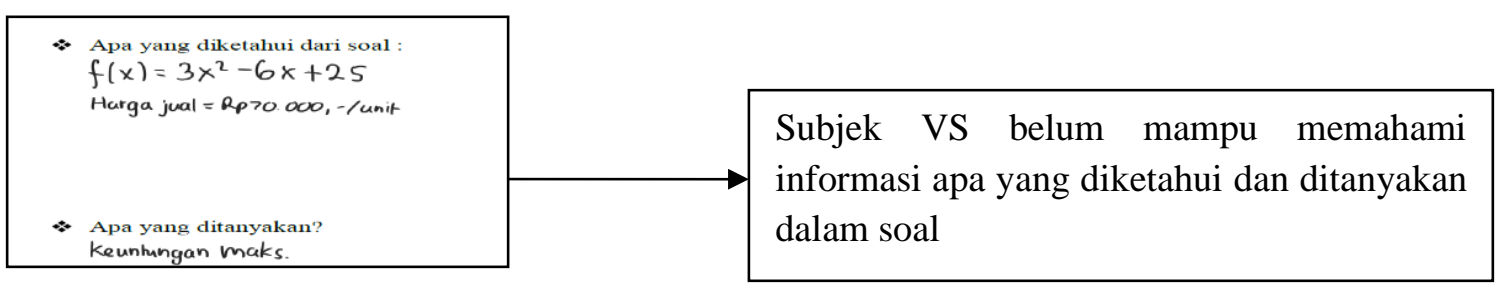

Gambar 1. Hasil pekerjaan pada siswa tahap memahami masalah. 
Subjek LS juga belum mampu menentukan kecukupan informasi untuk menjawab pertanyaan pada soal nomor satu dan belum pada soal nomor dua, karena nomor dua tidak ada angka. Pertanyaan dari peneliti pada indikator: "Apa informasi yang ada pada soal sudah cukup digunakan untuk menjawab masalah yang ditanyakan? Mengapa?" dan jawaban Subjek LS untuk soal nomor satu dan dua yaitu : "Iya." dan "Belum. Dan ini nggak ada angka sama sekali. Jadi, Itu yang cukup bikin tambah sulit, terus aku coba kait-kaitkan sama soal nomor satu." Sedangkan untuk kelima subjek lainnya informasi yang ada sudah cukup untuk mengerjakan soal yang ada. Selanjutnya pertanyaan peneliti pada indikator soal : “Apa yang diketahui dan ditanyakan dari soal tersebut?” Dan jawaban dari semua subjek menjawab sesuai dengan apa yang diketahui, yaitu soal nomor satu biaya produksi $\mathrm{x}$ unit : $(3 \times 2-6 \mathrm{x}+25) \mathrm{x}$ serta biaya penjualan $\mathrm{x}$ unit : 70x (kedua biaya diatas dalam ribuan rupiah) sedangkan soal nomor dua yaitu, jika ia tinggal a $\mathrm{km}$ dari tempat bekerja maka biaya transportasi adalah $\mathrm{r}$ rupiah per $\mathrm{km}$ per tahun serta biaya kontrakan adalah $\frac{q}{a+1}$ per tahun (dalam rupiah) dengan $\mathrm{q}$ dan $\mathrm{r}$ adalah konstanta bernilai positif dan $\mathrm{q}>\mathrm{r}$, dan ditanyakan yaitu soal nomor satu mencari keuntungan maksimum yang diperoleh perusahaan tersebut serta nomor dua yaitu mencari biaya minimum pengeluaran karyawan tersebut.

\section{Tahap Menyusun Rencana Pemecahan Masalah}

Pada tahap menyusun rencana pemecahan masalah diperoleh hasil bahwa keenam subjek tersebut melewati tahap ini. Subjek VPUR, subjek EA subjek JRA, subjek GHD, dan subjek VS melewati tahap ini dengan baik dan lancar berdasarkan hasil analisis tes dan wawancara. Namun subjek LS yang melakukan pemecahan masalah dengan asimilasi untuk soal nomor satu dan tidak menyusun rencana pemecahan masalah untuk soal nomor dua sehingga terjadi akomodasi. Dengan demikian dapat dikatakan bahwa subjek LS melakukan proses berpikir asimilasi yang salah ataupun proses berpikir akomodasi yang tidak sempurna untuk soal nomor dua.

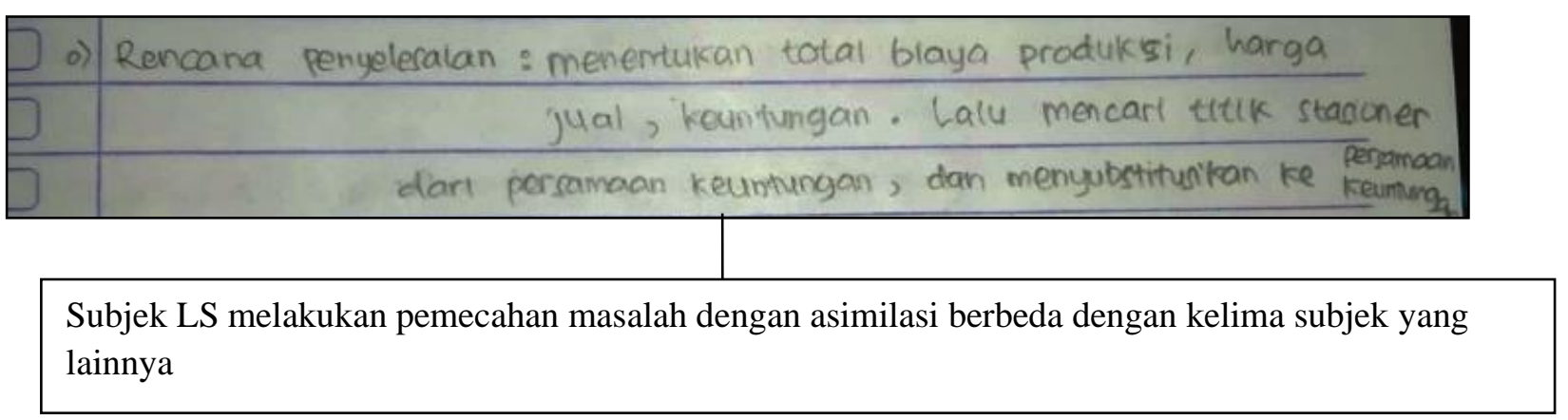

Gambar 2. Hasil pekerjaan siswa pada tahap menyusun rencana pemecahan masalah

Subjek LS belum mampu menyusun rencana pemecahan masalah dengan baik hal ini dilihat pada kutipan wawancara, pertanyaan dari peneliti pada indikator soal "Uraikan dengan jelas langkah-langkah yang akan kamu gunakan untuk menjawab soal tersebut!" dan jawaban dari Subjek LS untuk pertanyaan nomor dua, yaitu : “ Uhm...sebenarnya menurutku soalnya hampir sama dengan soal nomor satu tadi. Cuman ini yang dicari yang nilai minimum sedangkan nomor satu tadi itu carinya nilai maksimum. Dan ini nggak ada angka sama sekali. Jadi, uhm...Itu yang cukup bikin tambah sulit, terus aku coba kaitkaitkan sama soal nomor satu apa yang diketahui menurutku aku cari dulu buat persamaannya total 
persamaan pengeluaran terus cari biaya transportasi pertahun sama total pengeluaran minimum karyawan per tahun itu terus buat persamaannya. Aku nggak tahu eww benar atau salah. Total biaya pengeluaran karyawan aku misalkan sama $\mathrm{f}(\mathrm{a})$ terus biaya transportasi aku misalkan dengan $\mathrm{g}(\mathrm{a})$ dan $\mathrm{h}(\mathrm{a})$ ini aku dapat dari $\mathrm{f}(\mathrm{a}) \mathrm{g}(\mathrm{a})$, terus karena bingung jadi untuk cari fungsi stasionernya itu aku misalkan di $\mathrm{q}$ dan di soal yang diktehaui itu $\mathrm{q}>\mathrm{r}, \mathrm{q}=2$ dan $\mathrm{r}=1$ terus $u \mathrm{hm}$. dimasukan ke persamaannya fungsi stasioner, dan fungsi stasioner itu kan turunan h(a) tadi sama nol. Kemudian diturun-turunin sampai terakhir dan a nya itu ketemunya nol. Makanya masa nggak mungkin kan a nya km masa jaraknya sama dengan nol. Itu maaf itu hasil karangan. Akhirnya aku substitusi kepersamaan, gitulah yang ada dipikiran aku'. Sedangkan untuk subjek yang lainnya sudah menguraikan langkah-langkah yang digunakan pada soal sesuai dengan apa yang direncanakan, yaitu rumus pada soal nomor satu keuntungan $=$ biaya penjualan - biaya produksi, sedangkan rumus yang digunakan pada soal nomor dua yaitu biaya pengeluaran $(\mathrm{B})$ = biaya transportasi + biaya kontrakan, hanya pada subjek VS hasilnya kurang tepat karena kurang memahami pemecahan masalah.

\section{Tahap Melaksanakan Rencana Pemecahan Masalah}

Tahap melaksanakan rencana pemecahan masalah keenam subjek tersebut sudah melewati tahap ini berdasarkan hasil analisis tes dan wawancara. Subjek VPUR dan subjek JRA sudah melewati tahap ini dengan baik dan lancar. Sedangkan untuk subjek yang lainnya masih mengalami kesalahan pada tahap ini meskipun sudah merencanakan pemecahan masalah dengan rumus yang tepat, yaitu kesalahan subjek GHD, subjek EA dan subjek LS pada soal nomor satu ditampilkan pada gambar berikut ini.

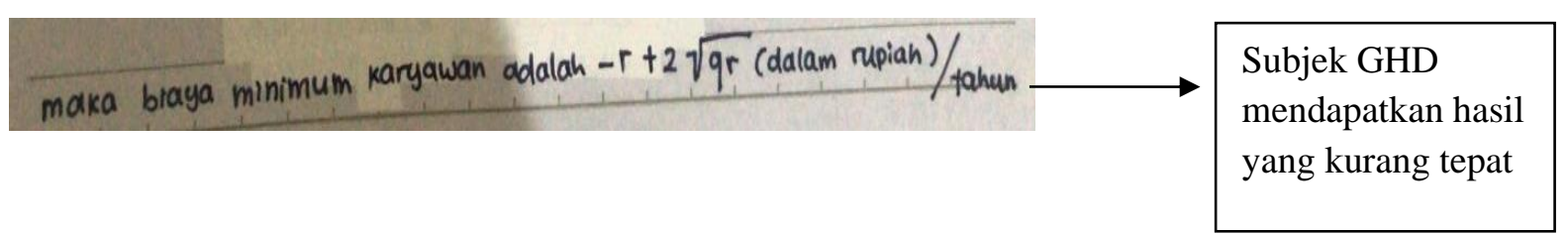

Gambar 3. Hasil pekerjaan siswa tahap melaksanakan rencana pemecahan masalah

$\mathrm{B}=\sqrt{\mathrm{q} r}-\mathrm{r}+\sqrt{q r}$
$\mathrm{~B}=2 \sqrt{\mathrm{qr}}-\mathrm{r}$$\longrightarrow$ Subjek EA mendapatkan hasil yang kurang tepat

Gambar 4. Hasil pekerjaan Siswa pada tahap melaksanakan rencana pemecahan masalah

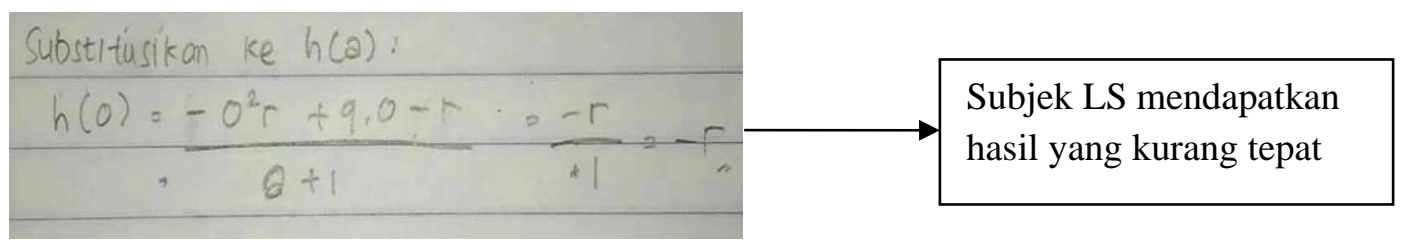

Gambar 5. Hasil pekerjaan siswa pada tahap melaksanakan rencana pemecahan masalah Berbeda halnya dengan Subjek VS belum tepat mengerjakan soal nomor satu dan dua. 


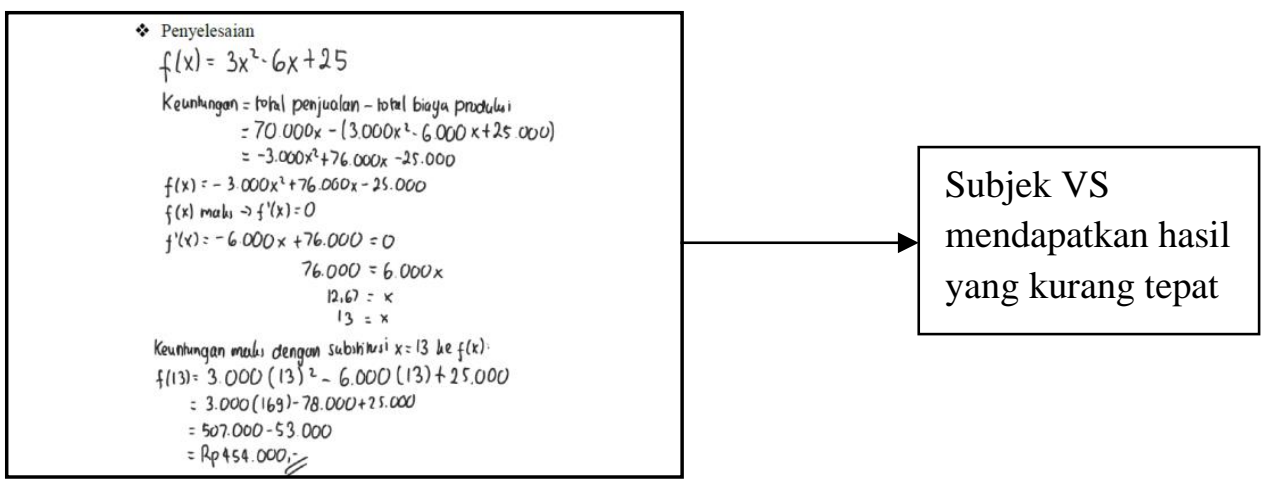

Gambar 6. Hasil pekerjaan siswa pada tahap melaksanakan rencana pemecahan masalah

Pertanyaan dari peneliti pada indikator soal "Apakah langkah-langkah yang kamu gunakan untuk menjawab soal tersebut sesuai dengan yang kamu rencanakan?” jawaban dari subjek VS untuk kedua butir soal, yaitu: "Iya", serta pertanyaan pada indikator soal "Apakah langkah yang kamu gunakan sudah benar? Mengapa?" dan jawaban subjek VS untuk kedua butir soal, yaitu: "Sudah". Berdasarkan wawancara subjek VS mengakui kalau jawabannya sudah tepat. Namun kenyataannya kedua butir soal kurang tepat. Sedangkan untuk subjek LS: "Nggak yakin", subjek LS tidak yakin dengan jawabannya. dan subjek EA: “Tidak yakin”. Untuk Subjek LS dan subjek EA belum yakin pada ketepatan jawabannya, sedangkan subjek yang lainnya sudah yakin pada ketepatan jawabannya.

\section{Tahap Memeriksa Kembali}

Untuk tahap memeriksa kembali keenam subjek ini sudah melewati tahap ini berdasarkan hasil tes dan wawancara. Tapi, hanya subjek VPUR yang melalui tahap ini dengan baik dan lancar pada kedua butir soal, hal ini dilihat pada gambar berikut.

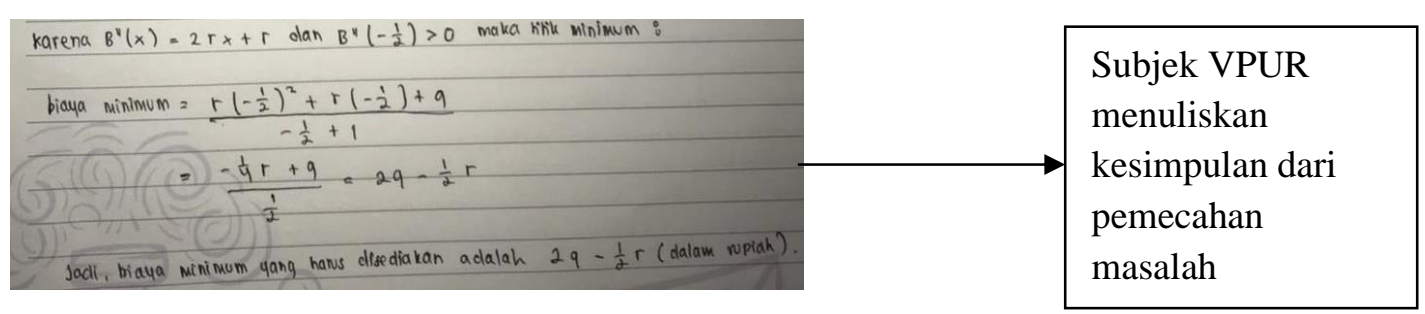

Gambar 7. Hasil gambar pekerjaan siswa pada tahap memeriksa kembali

Kelima subjek yang lainnya yaitu subjek GHD, subjek EA, subjek LS, subjek JRA dan subjek VS masih mengalami kesalahan yaitu belum lengkap menuliskan kembali kesimpulan jawaban dan belum meyakini kebenaran dari solusi masalah tersebut. Hasil pekerjaan subjek GHD, subjek EA, subjek LS, dan subjek VS mengosongkan bagian pengecekan kembali. Berbeda halnya dengan subjek JRA yang sudah menuliskan bagian pengecekan kembali. Tapi tidak menuliskan satuannya pada hasil akhir dan kesimpulan jawaban. Pertanyaan dari peneliti pada indikator soal, "bagaimana kamu melakukan pengecekan bahwa jawabanmu benar?” Jawaban dari subjek bervariasi subjek EA: “....”, subjek LS: "Meyakini kalau rumus yang saya gunakan sudah benar", subjek JRA: "Meyakini rumus", subjek VS: "Menuliskan kembali hasil akhir jawaban". Berdasarkan jawaban dari subjek ada yang diam, ada yang 
mengatakan bahwa dengan meneliti kembali jawabannya, meyakini kalau rumusnya tepat berarti jawabannya sudah tepat dan ada yang mengatakan dengan menulikan kesimpulan jawaban.

\section{Kemampuan Matematika}

\section{Kategori Kemampuan Matematika Tinggi}

Subjek dengan tingkat kemampuan matematika tinggi dalam tahap memahami masalah dilakukan dengan lancar dan benar oleh dua subjek. Subjek mampu menentukan apa yang diketahui dan ditanyakan dari soal serta mampu menentukan bahwa hal-hal yang diketahui sudah cukup untuk menjawab hal-hal yang ditanyakan. Hal ini sejalan dengan hasil penelitian yang dilakukan oleh Supriadi, D., Mardiyana., \& Subanti, S. (2015) bahwa Subjek dengan tingkat kecerdasan emosional tinggi dalam memahami masalah menggunakan proses berpikir pembentukan pengertian. Hal ini terlihat di mana subjek mampu menentukan syarat cukup (hal-hal yang diketahui) dan syarat perlu (hal-hal yang ditanyakan) serta mampu menentukan bahwa hal-hal yang diketahui sudah cukup untuk menjawab hal-hal yang ditanyakan. Dalam tahap menyusun rencana pemecahan masalah subjek mampu merencanakan penyelesaian atau pemecahan masalah dengan menggunakan rumus yang tepat. Hal ini sejalan dengan hasil penelitian yang dilakukan oleh Supriadi, D., Mardiyana., \& Subanti, S. (2015) bahwa subjek mampu menentukan hubungan antara hal-hal yang diketahui dengan hal-hal yang ditanyakan, konsep atau materi yang diperlukan, dan serta alternatif langkah-langkah penyelesaian pemecahan masalah. Dalam tahap melaksanakan rencana pemecahan masalah subjek mampu menggunakan langkah-langkah secara teratur, menuliskan langkah-langkah pemecahan masalah sesuai dengan yang direncanakan dan terampil dalam ketepatan menjawab soal satu subjek sudah, namun yang lainnya belum. Penyebab kesalahannya karena kurang teliti meskipun rumus yang direncanakan sudah tepat. Hal ini sejalan dengan hasil penelitian yang dilakukan oleh Supriadi, D., Mardiyana., \& Subanti, S. (2015) bahwa subjek menggunakan proses berpikir pembentukan kesimpulan atau penarikan kesimpulan. Hal ini terlihat di mana subjek mampu menggunakan langkah-langkah yang sudah direncanakan dan menggunakan algoritma perhitungan yang tepat untuk menjawab masalah. Dalam tahap memeriksa kembali jawaban pada tahap ini, satu subjek mampu menuliskan kembali kesimpulan jawaban tersebut dan meyakini kebenaran dari solusi masalah tersebut sedangkan subjek yang satunya belum. Penyebab kesalahan adalah kurang teliti. Hal ini sejalan dengan hasil penelitian yang dilakukan oleh Supriadi, D., Mardiyana., \& Subanti, S. (2015) bahwa subjek mampu mengecek kembali dan merasa yakin dengan langkah-langkah pemecahan masalah yang telah disusun.

\section{Kategori Kemampuan Matematika Sedang}

Subjek dengan tingkat kemampuan matematika sedang dalam tahap memahami masalah dilakukan dengan lancar dan benar oleh dua subjek. Subjek mampu menceritakan kembali maksud dari soal tersebut dengan kata-katanya sendiri, mampu menentukan apa yang diketahui dan ditanyakan dari soal serta satu subjek mampu menentukan bahwa hal-hal yang diketahui sudah cukup untuk menjawab hal-hal yang ditanyakan sedanhkan subjek yang kainnya belum. Hal ini sejalan dengan hasil penelitian yang dilakukan oleh Supriadi, D., Mardiyana., \& Subanti, S. (2015) bahwa subjek mampu menentukan 
syarat cukup (hal-hal yang diketahui) dan syarat perlu (hal-hal yang ditanyakan) serta mampu menentukan bahwa hal-hal yang diketahui sudah cukup untuk menjawab hal-hal yang ditanyakan. Dalam tahap menyusun rencana pemecahan masalah yang dilakukan oleh dua subjek. Satu subjek mampu merencanakan penyelesaian atau pemecahan masalah dengan menggunakan rumus yang tepat sedangkan subjek yang lainnya belum. Penyebab kesalahan siswa karena kurang memahami materi tersebut. Hal ini sejalan dengan hasil penelitian yang dilakukan oleh Supriadi, D., Mardiyana., \& Subanti, S. (2015) bahwa dalam membuat rencana pemecahan masalah, subjek menggunakan proses berpikir pembentukan pendapat. Dalam tahap melaksanakan rencana pemecahan masalah oleh dua subjek, satu subjek mampu menggunakan langkah-langkah secara teratur, menuliskan langkah-langkah pemecahan masalah sesuai dengan yang direncanakan serta belum terampil dalam ketepatan menjawab soal oleh kedua subjek. Penyebab kesalahan siswa karena kurang teliti dan kurang memahami materi. Hal ini sejalan dengan hasil penelitian yang dilakukan oleh Supriadi, D., Mardiyana., \& Subanti, S. (2015) bahwa subjek mampu menggunakan langkah-langkah yang sudah direncanakan dan menggunakan algoritma perhitungan yang tepat untuk menjawab masalah. Dalam tahap memeriksa kembali jawaban oleh dua subjek, satu subjek mampu menuliskan kembali kesimpulan jawaban tersebut dan bekum mampu meyakini kebenaran dari solusi masalah tersebut. Penyebab kesalahan karena tidak memahami materi dan mengakui bahwa jawabannya mengarang. Hal ini sejalan dengan hasil penelitian yang dilakukan oleh Supriadi, D., Mardiyana., \& Subanti, S. (2015) subjek mampu mengecek kembali dan merasa yakin dengan langkah-langkah pemecahan masalah yang telah disusun.

\section{Kategori Kemampuan Matematika Rendah}

Subjek dengan tingkat kemampuan matematika rendah dalam memahami masalah dilakukan dengan lancar dan benar oleh dua subjek. Satu subjek mampu menceritakan kembali maksud dari soal tersebut dengan kata-katanya sendiri, mampu menentukan apa yang diketahui dan ditanyakan dari soal sedangkan yang lainnya belum, serta mampu menentukan bahwa hal-hal yang diketahui sudah cukup untuk menjawab hal-hal yang ditanyakan. Dalam tahap menyusun rencana pemecahan masalah yang dilakukan oleh dua subjek. Subjek mampu merencanakan penyelesaian atau pemecahan masalah dengan menggunakan rumus yang tepat. Dalam tahap melaksanakan rencana pemecahan masalah oleh dua subjek, satu subjek mampu menggunakan langkah-langkah secara teratur hanya pada soal nomor satu, menuliskan langkah-langkah pemecahan masalah sesuai dengan yang direncanakan dan terampil dalam ketepatan menjawab soal, namun yang belum untuk subjek lainnya. Penyebab kesalahan siswa karena kurang teliti dan kurang memahami materi. Hal ini sejalan dengan hasil penelitian yang dilakukan oleh Supriadi, D., Mardiyana., \& Subanti, S. (2015) bahwa dalam melaksanakan rencana pemecahan masalah, subjek menggunakan proses berpikir pembentukan kesimpulan atau penarikan kesimpulan yang kurang sempurna. Dalam tahap memeriksa kembali jawaban oleh dua subjek, dan belum mampu menuliskan kembali kesimpulan jawaban tersebut dan meyakini kebenaran dari solusi masalah tersebut. Penyebab kesalahan karena tidak memahami materi dan mengakui bahwa jawabannya sudah tepat. Tapi kenyataannya hasil kurang tepat pada kedua butir soal. Hal ini sejalan dengan hasil penelitian yang 
dilakukan oleh Supriadi, D., Mardiyana., \& Subanti, S. (2015) bahwa dalam tahap memeriksa kembali jawaban, subjek menggunakan proses berpikir pembentukan kesimpulan atau penarikan kesimpulan yang tidak sempurna. Hal ini terlihat dimana subjek mampu mengecek kembali tetapi tidak merasa yakin dengan langkah-langkah pemecahan masalah yang telah disusun.

\section{Perbedaan Gender}

\section{Laki-laki}

Subjek ditinjau dari gender laki-laki dalam tahap memahami masalah dilakukan dengan lancar dan benar oleh tiga subjek, mampu menceritakan kembali maksud dari soal tersebut dengan kata-katanya sendiri, mampu menentukan apa yang diketahui dan ditanyakan dari soal serta mampu menentukan bahwa hal-hal yang diketahui sudah cukup untuk menjawab hal-hal yang ditanyakan. Dalam tahap menyusun rencana pemecahan masalah dilakukan dengan lancar dan benar oleh ketiga subjek, yaitu mampu merencanakan penyelesaian atau pemecahan masalah dengan menggunakan rumus yang tepat. Berbeda halnya dengan hasil penelitian yang dilakukan oleh Soejadi dalam Aminah, A., \& Ayu Kurniawati, K. R. (2018) bahwa kesulitan yang paling banyak dialami oleh siswa laki-laki adalah kesulitan pada langkah pertama dan kedua, dimana siswa laki-laki tidak mengungkapkan informasi yang lengkap terutama apa yang ditanyakan oleh soal. Dalam tahap melaksanakan rencana pemecahan masalah yang dilakukan oleh tiga subjek, yaitu mampu menggunakan langkah-langkah secara teratur, menuliskan langkah-langkah pemecahan masalah sesuai dengan yang direncanakan dan terampil dalam ketepatan menjawab soal, satu subjeknya belum tepat dalam menjawab soal. Dalam tahap memeriksa kembali yang dilakukan oleh tiga subjek, yaitu satu subjek mampu menuliskan kembali kesimpulan jawaban tersebut dan meyakini kebenaran dari solusi masalah tersebut sedangkan kedua subjek yang lainnya belum. Hal ini sejalan dengan hasil penelitian yang dilakukan oleh Soejadi (Aminah, A., \& Ayu Kurniawati, K. R, 2018) bahwa subjek laki-laki juga mengalami kesulitan pada langkah terakhir yaitu menentukan hasil akhir. Rata-rata subjek laki-laki kurang teliti dalam menuliskan hasil akhir. Ini disebabkan tidak mengecek kembali apa yang diminta dari soal.

\section{Perempuan}

Subjek ditinjau dari gender perempuan dalam tahap memahami masalah dilakukan dengan lancar dan benar oleh tiga subjek, mampu menceritakan kembali maksud dari soal tersebut dengan kata-katanya sendiri, mampu menentukan apa yang diketahui dan ditanyakan dari soal oleh dua subjek sedangkan subjek lainnya belum serta mampu menentukan bahwa hal-hal yang diketahui sudah cukup untuk menjawab hal-hal yang ditanyakan oleh satu subjek. Penyebab kesalahan siswa karena kurang teliti dalam informasi yang diketahui dari soal. Dalam tahap menyusun rencana pemecahan masalah dilakukan oleh ketiga subjek, yaitu dua subjek mampu merencanakan penyelesaian atau pemecahan masalah dengan menggunakan rumus yang tepat, sedangkan subjek yang lainnya belum. Hal ini sejalan dengan hasil penelitian yang dilakukan oleh Soejadi (Aminah, A., \& Ayu Kurniawati, K. R, 2018) bahwa kesulitan yang dialami paling banyak oleh subjek perempuan yaitu pada langkah pertama dan langkah kedua. Dalam tahap melaksanakan rencana pemecahan masalah yang dilakukan oleh tiga 
subjek, yaitu kurang sempurna dalam menggunakan langkah-langkah secara teratur, menuliskan langkah-langkah pemecahan masalah sesuai dengan yang direncanakan dan kurang sempurna pada keterampilan dalam ketepatan menjawab soal. Dalam tahap memeriksa kembali yang dilakukan oleh tiga subjek, yaitu subjek kurang mampu dalam menuliskan kembali kesimpulan jawaban tersebut dan belum meyakini kebenaran dari solusi masalah tersebut. Hal ini sejalan dengan hasil penelitian yang dilakukan oleh Soejadi (Aminah, A., \& Ayu Kurniawati, K. R, 2018) bahwa perempuan siswa juga mengalami kesulitan pada langkah terakhir yaitu dalam menarik kesimpulan.

\section{KESIMPULAN}

Berdasarkan data yang diperoleh dan analisis data yang telah dilakukan dapat disimpulkan bahwa berdasarkan tiga siswa laki-laki dan tiga siswa perempuan kelas XII MIPA 2 SMA Kristen Satya Wacana Salatiga yang dipilih sebagai subjek penelitian, tipe kesulitan yang dilakukan berdasarkan tahapan Polya jika ditinjau dari tingkat kemampuan matematika siswa dan perbedaan gender maka siswa dengan kategori kemampuan matematika tinggi pada gender laki-laki yang melewati semua tahap pada langkah Polya dengan tepat, baik itu tahap memahami masalah, menyusun rencana pemecahan masalah, melaksanakan rencana pemecahan masalah dan memeriksa kembali, sedangkan siswa pada gender perempuan mengalami kesalahan pada tahap menyusun rencana pemecahan masalah dan melaksanakan rencana pemecahan masalah. Siswa dengan kemampuan matematika sedang dan rendah baik itu dari gender laki-laki dan perempuan masih mengalami kesalahan pada semua tahapan pada langkah Polya baik itu tahap memahami masalah, menyusun rencana pemecahan masalah, melaksanakan rencana pemecahan masalah dan tahap memeriksa kembali.

Berdasarkan hasil penelitian diatas, maka peneliti mengemukakan beberapa saran, yaitu: (1) Bagi Guru sebaiknya mengarahkan dan membantu siswa dalam merencanakan masalah untuk mempermudah menyelesaikan penyelesaian suatu masalah. (2) Bagi siswa hendaknya sering berlatih menyelesaikan soal pemecahan masalah agar lebih terlatih, khususnya pada turunan; (3) Bagi peneliti lain yang akan melakukan penelitian serupa, mengenai pedoman wawancara sebaiknya tidak berpedoman pada struktur wawancara. Hal ini bertujuan agar wawancara dapat berkembang sesuai dengan kondisi subjek di lapangan, selain itu juga perlu mempertimbangkan tingkat kemampuan matematika siswa.

\section{UCAPAN TERIMA KASIH}

Terima kasih disampaikan kepada SMA Kristen Satya Wacana Salatiga dan Pusat Studi Pendidikan Sains, Teknologi dan Matematika (e -SisTeM) UKSW.

\section{REFERENSI}

Aminah, A., \& Ayu Kurniawati, K. R. (2018). Analisis Kesulitan Siswa Dalam Menyelesaikan Soal Cerita Matematika Topik Pecahan Ditinjau Dari Gender. JTAM | Jurnal Teori Dan Aplikasi Matematika, 2(2), 118. https://doi.org/10.31764/jtam.v2i2.713 
Christinove, R. M., \& Mampouw, H. L. (2019). A Review of Solo Taxonomy on Students' Errors in High Mathematical Abilities in Calculating Definite Integral of Trigonometric Functions. Al-Jabar: Jurnal Pendidikan Matematika, 10(1), 11-20. https://doi.org/10.24042/ajpm.v10i1.3858

Ilmi, M. B., \& Rosyidi, A. H. (2016). MATHE dunesa. Jurnal Ilmiah Pendidikan Matematika, 1(5), 2129.

Irianti, N. P., Subanji, S., \& Chandra, T. D. (2016). Proses Berpikir Siswa Quitter dalam Menyelesaikan Masalah SPLDV Berdasarkan Langkah-langkah Polya. JMPM: Jurnal Matematika Dan Pendidikan Matematika, 1(2), 133. https://doi.org/10.26594/jmpm.v1i2.582

Kristianingsih, R. (2019). Kemampuan pemecahan masalah siswa menyelesaikan soal materi garis singgung lingkaran. AKSIOMA : Jurnal Matematika Dan Pendidikan Matematika, 10(2), 135-142. https://doi.org/10.26877/aks.v10i2.4643

Kristofora, M., \& Sujadi, A. A. (2017). Analisis Kesalahan Dalam Menyelesaikan Masalah Matematika Dengan Menggunakan Langkah Polya Siswa Kelas VII SMP. Prisma, 6(1), 9-16.

Leder, G. C., Forgasz, H. J., \& Jackson, G. (2014). Mathematics, english, and gender issues: Do teachers count?. Australian Journal of Teacher Education, 39(9), 2

Marlina, L. (2011). Penerapan Langkah Polya Dalam Menyelesaikan Soal Cerita Keliling dan Luas Persegi Panjang. Jurnal Elektronik Pendidikan Matematika Tadulako, 1(1), 2013.

Maiti, \& Bidinger. (1981). Journal of Chemical Information and Modeling, 53(9), 1689-1699.

Maulyda, M. A., Hidayati, V. R., Rosyidah, A. N. K., \& Nurmawanti, I. (2019). Problem-solving ability of primary school teachers based on Polya's method in Mataram City. Pythagoras: Jurnal Pendidikan Matematika, 14(2), 139-149. https://doi.org/10.21831/pg.v14i2.28686

Mu'min, S. A. (2013). Teori Pengembangan Kognitif Piaget. Jurnal AL-Ta'dib, 6(1), 89-99.

Netriwati. (2016). Analisis Kemampuan Pemecahan Masalah Matetamatis Berdasarkan Teori Polya Ditinjau dari Pengetahuan Awal Mahasiswa IAIN Raden Intan Lampung. Jurnal Pendidikan Matematika, 7(9), 181-190.

Nur, A. S., \& Palobo, M. (2018). 15067-40560-1-Pb. Jurnal Ma T Ema Tika K R Ea Tif-Inovatif, 9(2), 139-148.

Sam, H. N., \& Qohar, A. (2016). Pembelajaran Berbasis Masalah Berdasarkan Langkah - Langkah Polya untuk Meningkatkan Kemampuan Menyelesaikan Soal Cerita Matematika. Kreano, Jurnal Matematika Kreatif-Inovatif, 6(2), 156. https://doi.org/10.15294/kreano.v6i2.5188

Sugiyono. (2008). Metode Penelitian Bisnis.Alfabeta: Bandung.

Sugiyono. (2015). Metode Penelitian Kuantitatif, Kualitatif, dan R\&D. Bandung: Alfabeta.

Susilowati, AsihPutri, J. (2016). Profil Penalaran Siswa SMP Dalam Pemecahan. 1(2), 132-148.

Vilianti, Y. C., Pratama, F. W., \& Mampouw, H. L. (2018). Description of The Ability of Social Arithedical Stories by Study Problems by Students VIII SMP Reviewed from The Polya Stage. International Journal of Active Learning, 3(1), 23-32. 
Yulianto, G. D., Suastika, I. K., \& Fayeldi, T. (2019). Analisis Kemampuan Pemecahan Masalahmatematika Berdasarkan Langkah Polya Pada Materi Sistempersamaan Linear Dua Variabel Kelas VIII SMP PGRI 4 Kalipare Malang. Pi: Mathematics Education Journal, 2(1), 7 13. https://doi.org/10.21067/pmej.v2i1.2810

Yarmayani, A. (2016). Analisis Kemampuan Pemecahan Masalah Matematis Siswa Kelas XI Mipa Sma Negeri 1 Kota Jambi. Jurnal Ilmiah Dikdaya, 6(2), 12-19.

Yuwono, T., Supanggih, M., \& Ferdiani, R. D. (2018). Analisis Kemampuan Pemecahan Masalah Matematika dalam Menyelesaikan Soal Cerita Berdasarkan Prosedur Polya. Jurnal Tadris Matematika, 1(2), 137-144. https://doi.org/10.21274/jtm.2018.1.2.137-144

Zakiah, N. E., Sunaryo, Y., \& Amam, A. (2019). Implementasi Pendekatan Kontekstual Pada Model Pembelajaran Berbasis Masalah Berdasarkan Langkah-Langkah Polya. Teorema: Teori Dan Riset Matematika, 4(2), 111. https://doi.org/10.25157/teorema.v4i2.2706

Zhu, Z. (2007). Gender differences in mathematical problem solving patterns: a review of literature. International Education Journal, 8(2), 187-203. 